\title{
Plant defense responses in monocotyledonous and dicotyledonous host plants during root-knot nematode infection
}

\author{
Arnika Przybylska • Aleksandra Obrępalska- \\ Steplowska
}

Received: 22 October 2019 / Accepted: 13 April 2020/Published online: 29 April 2020

(C) The Author(s) 2020

\begin{abstract}
Background Root-knot nematodes (RKNs) Meloidogyne spp. - are a group of nematodes distributed worldwide that infect monocotyledonous and dicotyledonous crop species. Plant responses to RKNs have been described in many studies of various host plants. In the course of parasitism, RKNs induce the transcriptional reprogramming of host cells to establish giant cells. Nematode attack induces many mechanisms in host plants, including pathogen-associated molecular pattern (PAMP)-triggered immunity (PTI) and effectortriggered immunity (ETI). Research on plant-RKN interactions has shown the activation and suppression of the expression of genes encoding various defenserelated proteins.

Scope and conclusions In this review, our goal is to critically summarize current knowledge on monocotyledonous and dicotyledonous plant-Meloidogyne interactions, including data on the role of RKN effectors and nematode PAMPs in host plant defense responses.
\end{abstract}

Keywords Plant-nematode interaction · Plant defense · Effectors $\cdot$ Meloidogyne $\cdot$ Root-knot nematodes $(\mathrm{RKNs})$

Responsible Editor: Ulrike Mathesius.

\footnotetext{
A. Przybylska • A. Obrępalska-Stęplowska $(\bowtie)$

Department of Molecular Biology and Biotechnology, Institute of Plant Protection - National Research Institute, 20 Węgorka Street, 60-318 Poznań, Poland

e-mail: olaob@o2.p1
}

\section{Introduction}

Economic significance of root-knot nematodes (RKNs)

Meloidogyne spp. Göldi 1887 (Tylenchidae: Tylenchus) nematodes, also known as RKNs, are a group of nematodes distributed worldwide that contains more than 60 described species. These polyphagous and highly adapted plant parasites have a very wide host range. The most economically important RKN species include Meloidogyne hapla, M. incognita, M. javanica, and M. arenaria (Jones and Goto 2011; Moens et al. 2009). Another well-analyzed Meloidogyne species is M. graminicola, which is primarily a pathogen of rice (Kumari et al. 2016; Kumari et al. 2017; Kyndt et al. 2012; Nahar et al. 2011). There are also two quarantined RKN species included on the EPPO A2 list: M. chitwoodi and M. fallax (A2 List of pests recommended for regulation of quarantine pests 2017). These two species parasitize monocotyledons and dicotyledons, including several species of crop plants, such as potatoes, carrots and tomatoes (EPPO 2016). M. chitwoodi has been reported in Argentina, Belgium, France, Germany, the Netherlands, Portugal, the USA, Mexico, and South Africa, while M. fallax has been reported in Belgium, France, Germany, the UK, Switzerland, New Zealand, Australia, and South Africa (EPPO 2016). The main crops infected by RKNs in fields or in greenhouses are potato, tomato, carrot, rice, sunflower, corn, sugar beet, pepper, and tobacco; however, the damage caused by RKNs is often overlooked, and information on their economic impact on agriculture is limited (Wesemael et al. 2011). 
The responses of plants to Meloidogyne infection have been analyzed by many research groups using different host plants. In this review, we summarize the information obtained so far on plant-Meloidogyne interactions. The role of nematode effectors in this process is also addressed.

\section{Infection process}

RKNs in the J2 invasive stage migrate in the soil, penetrate the root tip epidermis, and move inside roots through intercellular spaces. They establish giant cells by the transcriptional reprogramming of the parenchymal cells surrounding the phloem (Jones 1981). Giant cells are formed in a similar way for all Meloidogyne species and they have a feeding function. They are generated without cytokinesis but through sequential mitoses what leads to an increase of a size of a cell and a number of nuclei (Rodiuc et al. 2014). After J2 invasion, the expression of a broad spectrum of genes with many different functions is induced, which is correlated with wound and defense responses; changes in the cell wall, cell cycle and cytoskeleton organization; and morphological symptoms (Gheysen and Fenoll 2002).

Chemical and physical barriers and cell metabolism reprogramming

The first line of the plant defense system after RKN infection includes physical barriers, such as the cell wall, waxes or hairs, and chemical barriers, including enzymes or secondary metabolites (Jones and Dangl 2006). The first barrier to overcome by nematodes is usually the cell wall, which could also be covered with a cuticle. To overcome this obstacle, nematodes use a combination of mechanical penetration with its hollow mouth stylet together with an arsenal of virulence factors, including many cell wall-degrading enzymes (Jones and Goto 2011; Malinovsky et al. 2014). Among them, the presence and expression of plant cell wall degrading factors, such as $\beta$-1,4-endoglucanase, a functional polygalacturonase or a pectate lyase, was confirmed (Huang et al. 2005; Jaubert et al. 2002; Rosso et al. 1999). The primary cell wall is composed of hemicellulose polysaccharides and the heteropolysaccharide pectin interwoven within a cellulose microfibril network (Endler and Persson 2011). The walls of the different types of plant cells are specifically adapted to particular functions (Bradley et al. 1992). The composition of the plant cell wall can be altered by environmental stimuli in response to biological stresses (Bradley et al. 1992). Thus, mechanical wounding, infection, or elicitors obtained from pests and pathogens can stimulate the synthesis of lignin in peripheral tissues. These changes in cell wall composition constitute a part of inducible defense mechanisms (Malinovsky et al. 2014). In response to an attack, plants may deposit phenolic and callose complexes which have a reinforcing function, and produce toxic compounds (Hückelhoven 2007). When this barrier is overcome, other plant surveillance systems are activated (Malinovsky et al. 2014). Interestingly, Shah et al. (2017) hypothesized that RKN do not cause damage during their migration inside the root. Moreover, Teixeira et al. (2016) found that Arabidopsis lines with altered damage perception do not show any change in susceptibility to RKNs infection. Another recent study investigated the role of suberin and lignin-based Casparian strips and the fate of endodermis in roots during RKN infection. On the basis of the obtained results, the authors assumed that a functional endodermis is an obstacle to nematode penetration and contributes to defense mechanisms against RKNs (Holbein et al. 2019).

During feeding site formation (giant cells), nematodes induce the reprogramming of the metabolism of the roots by adjusting the expression patterns of root tipspecific genes or induce the expression of genes that are not usually expressed in the roots. A characteristic feature of giant cells is their outstanding isotropic growth (Sobczak et al. 2011). Such cell expansion requires extensive and coordinated cell wall remodeling. The expression of many cell wall-modifying enzymes, including expansins, endoglucanases, extensins, hydrolases, and structural proteins, is changed after Meloidogyne spp. infection (Sobczak et al. 2011). Wall extension involves the loosening of the cellulose/crosslinking glycan network, which is achieved through endo- $\beta$-D-glucanases, expansins and xyloglucan endotransglycosylases (Caillaud et al. 2008). The concomitant deposition of newly synthesized cell wall material is associated with this loosening process, and throughout feeding site development, further modifications to the cell wall result in wall thickening and the development of wall ingrowths (Caillaud et al. 2008).

Molecular mechanisms of plant defense

The presence of plant pathogens is revealed by recognizable molecular signals called pathogen-associated 
molecular patterns (PAMPs) located on their surfaces as well as by damage-associated molecular patterns (DAMPs) released by the disrupted host plant tissues. PAMPs are often perceived at low concentrations and induce specific defense responses (Manosalva et al. 2015). The first layer of defense is designated innate immunity or basal resistance, which can be triggered once the plant cells recognize PAMPs and DAMPs. PAMPs and DAMPs are recognized by pattern recognition receptors (PRRs), resulting in pattern-triggered immunity (PTI), which can halt further colonization by RKNs (Jones and Dangl 2006). One of the first PRRs described for nematodes was a leucine-rich repeat (LRR)-RLK encoded by the Arabidopsis thaliana nilr1 gene (nematode-induced LRR-RLK 1), which is widely conserved among dicots and monocots (Mendy et al. 2017). When innate immunity is suppressed by pest effectors, effector-triggered susceptibility (ETS) is induced, and a given effector is recognized by the appropriate proteins in plants, resulting in effector-triggered immunity (ETI) (Jones and Dangl 2006). On the other hand, when the host presents disease resistance, ETI is accelerated, and the PTI response is amplified. Moreover, it usually results in a hypersensitive cell death response (HR) at the infection site (Jones and Dangl 2006). RKNs evolved to avoid ETI by acquiring additional effectors that may suppress ETI as well as by shedding or diversifying the recognized effector gene. The suppression of ETI by effectors is effective in a susceptible host and results in ETS, which allows the nematode to infect the plant (Jones and Dangl 2006).

Jasmonic acid and salicylic acid pathways

Part of the PTI response induced by PAMPs during plant resistance occurs via conserved signal transduction mechanisms, including the activation of mitogenactivated protein kinases (MAPKs), generation of reactive oxygen species (ROS) and activation of the salicylic acid (SA) and jasmonic acid (JA) signaling pathways (Manosalva et al. 2015). SA regulates many genes encoding pathogenesis-related (PR) proteins, including PR1 and most acidic PR proteins, while the JA signaling pathway affects the expression of genes encoding defensin, thionin, PR3 and PR8 proteins (Reymond and Farmer 1998). Recent studies have suggested that JA may play a dominant role in plant-pathogen interactions in the roots of monocotyledons and dicotyledonous plants, including plant-RKN interactions (Fujimoto et al. 2011; Mendy et al. 2017; Nahar et al. 2011). Cross talk between the JA/ET and SA defense signaling pathways has been shown to optimize the response against a single attacker (Spoel et al. 2007).

The pathways induced during the plant response to nematode infection are summarized in the scheme below (Fig. 1).

\section{Plant resistance genes against RKNs}

As described above, the HR reaction can be activated by the gene-for-gene resistance mechanism. The gene-forgene concept assumes that for each gene that causes a reaction in the host, there is a corresponding gene in the parasite that is responsible for pathogenicity (Flor 1971). The appropriate activation of host defense responses is mediated by disease resistance $(R)$ genes that have a dual function of directly or indirectly recognizing specific avirulence $(a v r)$ factors and subsequently activating host signal transduction pathways, leading to physiological changes that make conditions in the host plant unfavorable for nematode survival (Kaloshian et al. 2011). The most well-known plant $R$ gene against RKNs is the $M i$ 1.2 gene from tomato. In plants carrying this gene, HR stops the nematode from establishing a feeding site. Mi1.2-mediated resistance can dramatically reduce RKN survival, reproduction and gall induction (Corbett et al. 2011). The Mi-1.2 gene is present in many tomato cultivars and confers resistance to three common RKN species, M. incognita, M. javanica and M. arenaria, and three insect species, potato aphid (Macrosiphum euphorbiae), sweet potato whitefly (Bemisia tabaci) and tomato psyllid (Bactericera cockerelli) (Corbett et al. 2011). Importantly, Mi-1.2-mediated resistance has some limitations. Tomato plant resistance is dependent on soil temperature. At temperatures higher than $28^{\circ} \mathrm{C}$, the $M i$ 1.2 gene becomes inactive, and at $32{ }^{\circ} \mathrm{C}$, the plant becomes sensitive (Dropkin 1969). Moreover, Mi-1.2-mediated resistance is effective only against the three aforementioned species but is ineffective against other harmful RKN species, such as M. enterolobii and M. hapla (ElSappah et al. 2019; Kiewnick et al. 2009). There are also reports on nine other root-knot nematode resistance genes in wild species of tomato: $M i-2$ to $M i-9$ and MiHT, but unlike $M i-1.2$, they have not been successfully transferred to cultivated tomatoes (Rashid et al. 2017; Wu et al. 2009). There are also some studies that indicate that the Me resistance gene in pepper (Capsicum annuum) confers resistance to RKNs (Djian-Caporalino et al. 2007) 


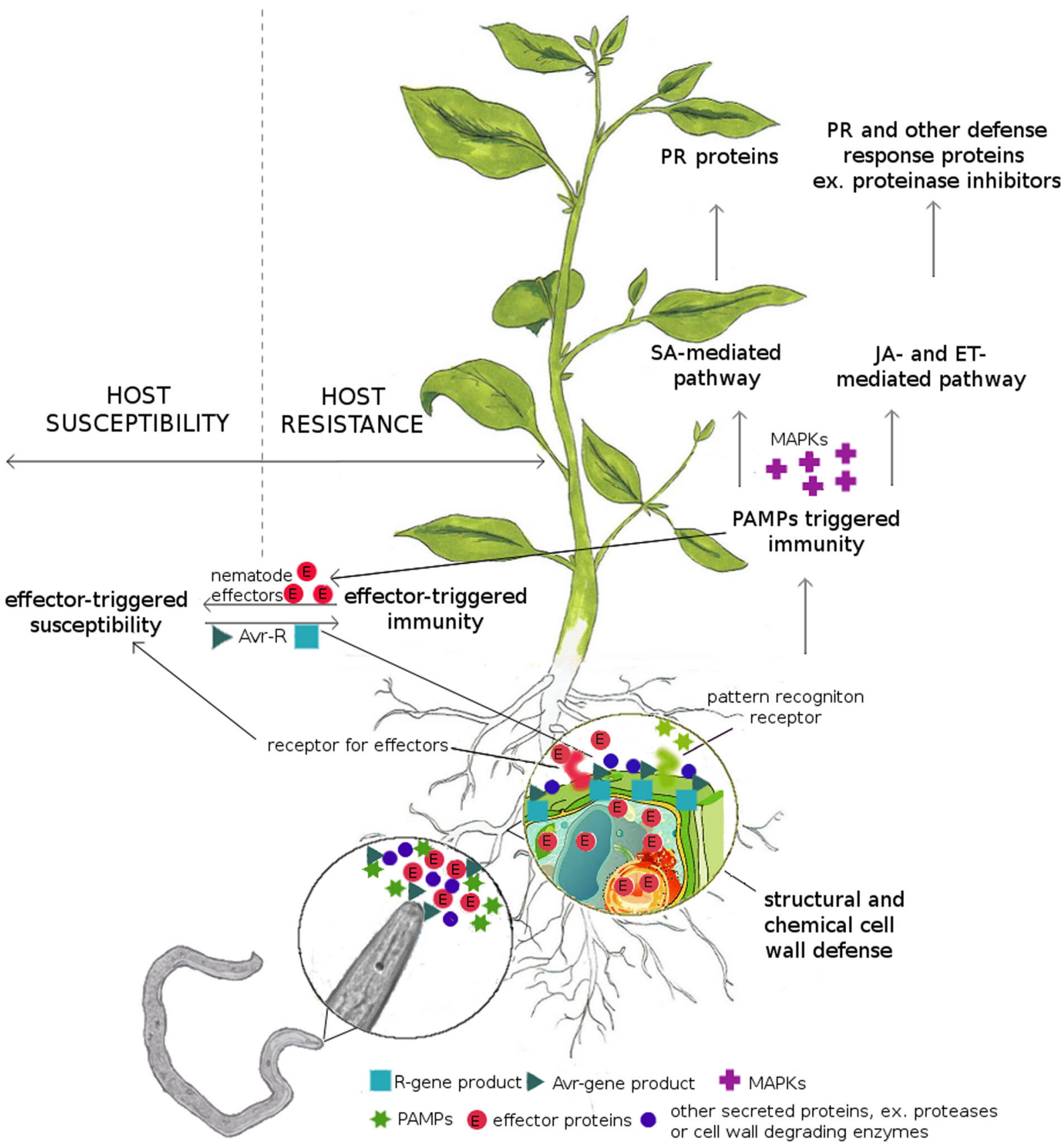

Fig. 1 Scheme of the pathways induced during the plant response to nematode infection. PR proteins - pathogen-related proteins, $\mathrm{SA}$ - salicylic acid, JA - jasmonic acid, ET - ethylene, $R$ gene -

and that the Mex-1 gene in coffee (Coffea arabica) confers resistance to M. exigua (Noir et al. 2003).

Several review articles address the interactions between plants carrying resistance genes and RKN species (Barbary et al. 2015; El-Sappah et al. 2019; Rashid et al. plant resistance gene, avr-gene - gene encoding an RKN avirulence factor, MAPKs - mitogen-activated protein kinases, PAMPs - pathogen-associated molecular patterns

2017; Roberts 1992; Seid et al. 2015). In addition, there are also recent review articles presenting in a broader sense some topics associated with the field of plant parasitic nematode-plant interactions (Kaloshian and Teixeira 2019; Sato et al. 2019; Siddique and Grundler 
2018), including nematode effectors and other secreted proteins (Mejias et al. 2019; Vieira and Gleason 2019). Here, in addition to general aspects of plant-RKN interactions, we focused largely on discussing the processes taking place separately in monocotyledonous and dicotyledonous hosts and RKNs.

Nematode PAMPs that activate the host plant PTI response

Ascarosides and elicitor(s) presented in NemaWater (water obtained after removing the preinfected $\mathrm{J} 2$ larvae after $24 \mathrm{~h}$ of incubation (Mendy et al. 2017)) are the only nematode PAMPs that have been described so far. This PAMPs activate the initial of PTI responses in their hosts (Mendy et al. 2017).

Ascarosides constitute an important group of proteins produced by RKNs that may affect plant defense responses (Manosalva et al. 2015). More than 200 different ascarosides derived from over 20 nematode species have been described, indicating that ascarosides are a highly conserved group of nematode proteins. Ascarosides are recognized by plants as NAMPs (nematode-associated molecular patterns), which induce the activation of conserved immune responses in host plants and, as consequence enhance plant resistance to a wide spectrum of pests and pathogens. The protein designated asrc\#18 was analyzed in more detail. The authors who studied ascr\#18 suggested that the systemic induction of defense genes and $\mathrm{RKN}$ resistance in leaves following root application of ascr\#18 may indicate that this protein moves from the roots to the leaves and/or that ascr\#18 induces the synthesis of a mobile signal in the roots that is then transmitted to the leaves to activate immune responses (Manosalva et al. 2015).

A study on NemaWater showed that NemaWater treatment triggers PTI responses, such as immune gene expression and ROS burst and, as a consequence, can inhibit seedling growth (Mendy et al. 2017). The obtained results may suggest the presence of putative elicitor(s) in NemaWater. The identity of the elicitor(s) remains unknown, but according to the results of the study, it may be a heat-sensitive protein(s) (Mendy et al. 2017). Using NemaWater is a relatively new and unique approach and may have some limitations in the accurate representation of in vivo infection processes.

\section{Role of RKN effector proteins in host plant defense responses}

Nematodes have three large specialized secretory gland cells in the esophagous, one dorsal and two subventral, and these cells are the principal sources of effectors essential for phytonematodes to parasitize plants (Hussey 1989). In recent years, several research papers have focused on the characterization of nematode effectors. The first nematode parasitic genes expressed in the esophageal gland cells were identified in the cyst nematodes Heterodera spp. and Globodera spp., which encode $\beta$-1,4-endoglucanases (cellulases) (Smant et al. 1998; Yan et al. 1998). It has also been suggested that effectors secreted by nematodes contribute to plant defense suppression during infection (Davis et al. 2008; Rosso et al. 2012). Huang et al. (2003) obtained a profile of 37 cDNA sequences encoding candidate effector proteins expressed exclusively within the secretory esophageal gland cells of $M$. incognita throughout the parasitic cycle by combining the expressed sequence tag (EST) analysis of a gland-cell LD-RT-PCR cDNA library with high-throughput in situ screening of the clones encoding a signal peptide for secretion. To date, several effectors encoded by RKNs have been reported. Their mode of action and different functions in plantRKN interactions are briefly described below, and the effectors are also discussed in other review articles in additional detail (Mejias et al. 2019; Vieira and Gleason 2019).

One of the most important modes of action of RKN effectors is the suppression of plant cell death associated with PTI or/and ETI response. To effectors with such a function belong the effector Mi-CRT, calreticulin, described for M. incognita (Dubreuil et al. 2009; Jaouannet et al. 2013). The knockdown of gene encoding Mi-CRT in preparasitic infective juveniles resulted in a reduced ability of the nematodes to induce galls on tomato (Dubreuil et al. 2009). In addition, Jaouannet et al. (2013) in their research on A. thaliana provided evidence for the manipulation of the plant basal immune response by the Mi-CRT protein, with a direct effect on PTI suppression. They observed that the induction of marker defense genes was strongly suppressed in plants in which Mi-CRT was secreted by the nematodes to the apoplast. Another $M$. incognita effector that is able to manipulate plant immunity is the Msp40 protein (Niu et al. 2016). It was demonstrated that Msp40 may suppress PTI and ETI by targeting 
common components, such as the elements of MAPK cascades, or by interacting with diverse components of these two immunity pathways in A. thaliana plants. The expression of another protein, the MiSGCR1 effector, which is secreted by $M$. incognita and is specifically involved in the early stages of plant-nematode interaction, may suppress cell death (Nguyen et al. 2018). There is also an effector, MeTCTP, described for M. enterolobii (Zhuo et al. 2017). The TCTP family of proteins is highly conserved and has been suggested to have various functions, such as calcium binding, histamine release, protection against stress, antiapoptosis and microtubule stabilization (Zhuo et al. 2017). The effector MeTCTP is expressed specifically within the nematode dorsal esophageal gland and is localized to the cytoplasm of plant cells. The authors discovered that host susceptibility increased with an increased expression level of MeTCTP, suggesting that the MeTCTP effector contributes to $M$. enterolobii virulence. Additionally, this protein has been suggested to function in the suppression of defense-related host cell death. Interesting results were also obtained for RKN lectin, which was experimentally demonstrated to be secreted into host plants as an effector, e.g., Mg01965 from $M$. graminicola. This protein is released during the early stages of infection and accumulates in the apoplast, where it can suppress PTI, possibly by binding to certain apoplastic sugars and by interfering with sugar signals (Zhuo et al. 2019). Effector proteins can also be conserved between some economically important Meloidogyne species, such as M. hapla, M. incognita, and $M$. graminicola, as described in the example of the Msp18 protein (Grossi-de-Sa et al. 2019). The results of this study suggested that this effector suppresses programmed cell death mediated by immune defenses to achieve successful parasitism in the host plant.

Other effectors can interfere with SA- and/or JAmediated pathways. An example of that kind of protein can be the M. incognita Misp12 effector examined on Nicotiana benthamiana plants. This protein was suggested to be involved in the downregulation of SA- and JA-dependent defense response genes to enhance $M$. incognita parasitism during the mature stages of the nematode life cycle (Xie et al. 2016). On the other hand, Wang et al. (2018) characterized a novel chorismate mutase from $M$. incognita, Mi-CM3, which regulated the SA pathway in such a way that enhanced nematode parasitism. Mi-CM3 disrupts SA biosynthesis and SAmediated defense in the plant tissues in which this gene is expressed.The presence of a chorismate mutase was also reported in M. javanica species (MjCM-1), and the authors assumed that this protein has the potential to be a multifunctional enzyme responsible for promoting nematode pathogenicity (Doyle and Lambert 2003). In addition, the MiISE5 effector, described in M. incognita, may participate in the manipulation of several pathways in host plants during the infection process, such as the regulation of transcription and the inhibition of the expression of multiple marker genes in response to various biotic and abiotic stimuli. In addition, the overexpression of MiISE5 in Arabidopsis also modified host hormones from both the JA- and SA-mediated signaling pathways. These lines of evidence suggest that MiISE5 plays an important role in nematode parasitism (Shi et al. 2018b). The same authors described that the MiISE6 effector protein, which was highly expressed in the early parasitism stages, has a functional signal peptide and can localize to the nucleus. It was suggested that MiISE6 can enhance nematode parasitism by interfering with multiple signaling pathways in plants, especially by the upregulation of genes encoding the jasmonate ZIM-domain (JAZ) protein family, which are known to be repressors of the JA signaling pathway (Shi et al. 2018a).

Some other effector proteins can also bind actin monomers to manipulate plant actin in conjunction with the enhancement of the expression of the genes encoding endogenous actin-depolymerizing factor (ADF), as described for MiPFN3 in M. incognita by Leelarasamee et al. (2018). Their results suggested that diminishing actin network density was important to facilitate nematode feeding. There is also a report about the Mh265 effector protein from M. hapla (Gleason et al. 2017). The authors found that $A$. thaliana expressing this protein exhibited enhanced susceptibility to RKNs, which may indicate the role of this protein in plant defense mechanisms. Moreover, the effector protein MjTTL5 from M. javanica promotes plant ROSscavenging activity and suppresses host defenses (Lin et al. 2016). For another effector protein, $\operatorname{Mg} 16820$, encoded by $M$. graminicola and localized in the apoplast, cytoplasm and nucleus of plant cells, the potential target protein in plants is dehydration-stress inducible protein 1 (DIP1), which was reported as an ABA-responsive gene (Naalden et al. 2018). Mg16820 functions in the apoplast and in the cytoplasm by interacting with components important in ROS defense signaling, which may suggest that this protein is able to 
interfere with two different mechanisms to suppress the immune system of the plant. Another mode of action has MgGPP protein from M. graminicola. Experimental evidence has suggested that MgGPP may be secreted into host plants during parasitism; first, MgGPP is secreted into the cell apoplast before entering the cells, then it is targeted to the endoplasmic reticulum (ER), where $\mathrm{N}$-glycosylation and $\mathrm{C}$-terminal proteolysis occur, and finally, it is translocated from the ER to the nucleus (Chen et al. 2017). Effector proteins can also play a role in the suppression of basal defense in plants in other ways, such as MgMO237 encoded by M. graminicola. This effector interacts with three rice proteins (OsGSC, OsCRRSP55 and OsBetvI) that are all host defense-related proteins (Chen et al. 2018).

The described RKN effectors and their localization and function in parasitism are summarized in Table 1.

\section{Plant defense mechanisms induced in monocotyledonous plants}

Many studies have been conducted to elucidate the plant response to Meloidogyne infection for both mono- and dicotyledonous plants; however, most of the research has been conducted on dicotyledonous plants (Table 1). Two types of interactions with different host varieties can be considered: compatible, where the host plant is susceptible to RKN infection, and incompatible, where the host plant is resistant.

\section{Compatible interactions}

Most of the studies on the response of monocotyledons to RKN infection utilized the M. graminicola-Oryza sativa pathosystem. One study showed that M. graminicola and M. incognita nematodes were able to suppress the expression of rice basal defense genes at early stages after infection (Nguyễn et al. 2014). The authors determined that the gene MAPK5 $a$ encoding the kinase involved in phosphorylation cascades in PTI and ETI was downregulated after infection. Other studies conducted on rice reported that part of the PTI signaling response, which is a JA-mediated pathway, plays an important role in plant defense responses. In addition, the consistent local downregulation of major defenserelated genes, such as PR10, WRKY45 or PR1b, in nematode-induced root galls at an early stage of infection has been reported (Nahar et al. 2011). Some authors also indicated that both JA- and SA-mediated rice defenses are activated during the early stages of $M$. graminicola infection, but these responses were suppressed during the later stages of infection (Kumari et al. 2016, 2017). In another study conducted on rice, the genes encoding AOS2 (allene oxide synthase, one of the enzymes in the JA biosynthesis pathway), PAD4 (phytoalexin deficient 4, part of the SA-dependent response) and WRKY13 (positive transcriptional regulator of defense genes) were downregulated after nematode infection (Nguyễn et al. 2014). Interestingly, the significant upregulation of ABA response marker genes, such as OsZEP or OsLip9, in the sensitive variety of O. sativa infected by M. graminicola was observed (Kyndt et al. 2017). On the other hand, during $M$. arenaria infection in maize, changes in the expression levels of genes encoding proteins involved in both the SA and JA pathways and the downregulation of other defenserelated genes, such as peroxidase, catalase or superoxide dismutase, were reported at the early stage of nematode infection (as early as $1 \mathrm{dpi}$ ) (Przybylska et al. 2018). The results obtained for Musa acuminate provided evidence for the early host defense responses that involved the downregulation of the expression level of the genes encoding ROS and JA/ET signaling-related proteins. In addition, Kyndt et al. (2012) found evidence that RKNs suppress the SA-mediated pathway in the systemic tissues of infected rice plants. Moreover, RKNs have been shown to modulate the ET pathway and induce the production of methyl jasmonate (MeJA) to promote successful infection of the plant. Among studies performed on Zea mays, Gao et al. (2008) tested mutants lacking lipoxygenase $(\mathrm{Z} m L O X 3)$ and found that there was an increased level of JA in the roots but not in the leaves and increased susceptibility to $M$. incognita.

Incompatible interactions

There are several studies on resistant varieties of rice revealing that both JA- and SA-mediated host defenses are activated 2 days postinfection, and in contrast to sensitive varieties, this activity can still be observed in later stages of infection (Kumari et al. 2016, 2017). Moreover, a study performed on maize infected with $M$. arenaria showed changes in the expression levels of genes encoding the PR3, PR4 and PR5 proteins, which may also suggest the role of JA- and SA-mediated pathways in host resistance (Przybylska et al. 2018). Alternatively, Starr et al. (2014) analyzed the expression 
Table 1 Nematode effectors and their role in parasitism

\begin{tabular}{|c|c|c|c|c|}
\hline Nematode & $\begin{array}{l}\text { Effector } \\
\text { protein }\end{array}$ & Localization & Function & Reference \\
\hline \multirow[t]{8}{*}{ M. incognita } & Mi-CRT & Apoplast & $\begin{array}{l}\text { Overproduction in plant cells increases plant } \\
\text { resistance to RKNs }\end{array}$ & $\begin{array}{l}\text { Jaouannet } \\
\text { et al. } 2013\end{array}$ \\
\hline & Msp40 & $\begin{array}{l}\text { Cytoplasm } \\
\text { and nucleus }\end{array}$ & Suppresses ETI-associated cell death & $\begin{array}{l}\text { Niu et al. } \\
2016\end{array}$ \\
\hline & Misp12 & Cytoplasm & $\begin{array}{l}\text { Participates in the maintenance of giant cells } \\
\text { during parasitism }\end{array}$ & $\begin{array}{l}\text { Xie et al. } \\
2016\end{array}$ \\
\hline & Mi-CM3 & $\begin{array}{l}\text { Cytoplasm } \\
\text { and nucleus }\end{array}$ & $\begin{array}{l}\text { Suppresses plant immunity by manipulating the } \\
\text { SA pathway at the early stage of nematode } \\
\text { parasitism }\end{array}$ & $\begin{array}{l}\text { Wang et al. } \\
2018\end{array}$ \\
\hline & MiPFN3 & Unknown & $\begin{array}{l}\text { Binds actin monomers to manipulate plantactin, } \\
\text { which must undergo reorganization for giant } \\
\text { cell formation }\end{array}$ & $\begin{array}{c}\text { Leelarasamee } \\
\text { et al. } 2018\end{array}$ \\
\hline & MiSGCR1 & $\begin{array}{l}\text { Cytoplasm } \\
\text { and nucleus }\end{array}$ & Suppresses plant cell death & $\begin{array}{l}\text { Nguyen et al. } \\
2018\end{array}$ \\
\hline & MiISE5 & Cytoplasm & $\begin{array}{l}\text { Interferes with various metabolic and signaling } \\
\text { pathways, especially SA- and JA-mediated } \\
\text { signaling pathways }\end{array}$ & $\begin{array}{r}\text { Shi et al. } \\
2018 b\end{array}$ \\
\hline & MiISE6 & Nucleus & $\begin{array}{l}\text { Interferes with various metabolic and signaling } \\
\text { pathways, especially the JA signaling pathway }\end{array}$ & $\begin{array}{r}\text { Shi et al. } \\
2018 \mathrm{a}\end{array}$ \\
\hline M. javanica & MjTTL5 & Plastids & $\begin{array}{l}\text { Encodes a transthyretin-like protein that may } \\
\text { suppress host defenses }\end{array}$ & $\begin{array}{l}\text { Lin et al. } \\
2015\end{array}$ \\
\hline M. hapla & $\operatorname{Mn} 265$ & Cytoplasm & Suppresses host defenses & $\begin{array}{l}\text { Gleason et al. } \\
2017\end{array}$ \\
\hline M. enterolobii & МeTCTP & Cytoplasm & Suppresses programmed cell death in host plants & $\begin{array}{l}\text { Zhuo et al. } \\
2017\end{array}$ \\
\hline \multirow[t]{4}{*}{ M. graminicola } & MgGPP & Nucleus & $\begin{array}{l}\text { Suppresses host defenses and enhances nematode } \\
\text { parasitism }\end{array}$ & $\begin{array}{l}\text { Chen et al. } \\
2017\end{array}$ \\
\hline & $\operatorname{MgMO} 237$ & $\begin{array}{l}\text { Cytoplasm } \\
\text { and nucleus }\end{array}$ & $\begin{array}{l}\text { Overexpression in plants increases plant } \\
\text { susceptibility to RKNs by suppressing the host } \\
\text { defense responses }\end{array}$ & $\begin{array}{l}\text { Chen et al. } \\
2018\end{array}$ \\
\hline & $\operatorname{Mg} 16820$ & $\begin{array}{l}\text { Apoplast, } \\
\text { cytoplasm } \\
\text { and nucleus }\end{array}$ & Suppresses both the PTI and ETI response & $\begin{array}{l}\text { Naalden et al. } \\
2018\end{array}$ \\
\hline & $\mathrm{Mg} 01965$ & Apoplast & Suppresses the PTI response & $\begin{array}{l}\text { Zhuo et al. } \\
2019\end{array}$ \\
\hline $\begin{array}{l}\text { Conserved among } M \text {. hapla, } M \text {. } \\
\quad \text { floridensis, } M \text {. incognita, } M \text {. javanica } \\
\text { and } M . \text { graminicola }\end{array}$ & Msp18 & $\begin{array}{l}\text { Cytoplasm } \\
\text { and nucleus }\end{array}$ & $\begin{array}{l}\text { Suppresses defense-related programmed cell } \\
\text { death }\end{array}$ & $\begin{array}{r}\text { Grossi-de-Sa } \\
\text { et al. } 2019\end{array}$ \\
\hline
\end{tabular}

level of the ZmPAL4 gene, which encodes phenylalanine ammonia lyase (the key enzyme in phenylpropanoid metabolism in plants, which is involved in plant responses to biotic and abiotic stresses), in maize varieties with different susceptibilities to $M$. incognita infection, and the results of this study indicated that the most tolerant inbred variety had the highest expression of this gene, which may suggest that the $P A L$ gene plays a role in modulating the susceptibility of maize to
M. incognita. Factors involved in the monocotyledonous host response to Meloidogyne infection and the processes analyzed in these interactions are listed in Table 2. Moreover the interaction between the Aloe vera plant and M. incognita and M. javanica was described by (Palomares-Rius et al. 2015), but the mechanism of the plant response has not been analyzed in detail. However, scientists have discovered that aloe plants possess a possible defense mechanism that affects the 
development and viability of RKN eggs laid inside the root. They suggested that this effect may be associated with the presence of certain phenolic compounds in infected tissues.

\section{Plant defense mechanisms induced in dicotyledonous plants}

Compatible interactions

Substantially more RKN interactions have been studied in dicotyledonous plants than in monocotyledonous plants. Many studies have indicated that the ET/JA pathway plays an important role in plant-nematode interactions. One such study carried out on tomato (S. lycopersicum) and M. javanica suggested that the expression pattern of the ethylene-responsive elements may reflect the involvement of ethylene in RKN parasitism (Bar-Or et al. 2005). Alternatively, Fan et al. (2015) stated that endogenous JA and exogenous MeJA are potent inducers of systemic root defense against $M$. incognita attack in this host. Fujimoto et al. (2011) found that multicystatin $(M C)$ and proteinase inhibitors $(P I s)$, the JA-responsive genes in tomato infected with $M$. incognita, may be important for RKN invasion and infection because a smaller number of egg masses were observed when RKNs were inoculated into plants overexpressing $M C$ and PIs. In addition, there have been studies suggesting the role of nitric oxide (NO) in the JA-dependent defense against $M$. incognita in tomato. NO is an essential regulatory molecule that has multiple functions in plants and has been widely observed in different plant species and organs under various biotic stress conditions (Zhou et al. 2015). Moreover, a study on soybean (Glycine max) showed that all of the allene oxide synthase family members were significantly downregulated in addition to other genes encoding enzymes involved in the JA signaling pathway (Ibrahim et al. 2011). It has also been shown that abscisic acid (ABA) synthesis and the JAand ET-mediated signaling pathways were downregulated in a susceptible variety of peanut (Arachis hypogea) (Clevenger et al. 2017). Therefore, the authors concluded that the downregulation of the JA/ET signaling pathways may enhance nematode susceptibility in peanut.

Alternatively, there have been reports that also showed an important role of SA and SAR induction in plants following nematode infection in tomato (Molinari et al. 2014). Research conducted on the tomato- $M$. incognita model showed that the components of ET, ABA and SA signaling were differentially regulated (Shukla et al. 2018). In addition, the genes encoding enzymes related to oxidative stress, including glutathione S-transferases, peroxidases and thioredoxins, were largely downregulated during the later stages of infection (Shukla et al. 2018). Studies on A. thaliana showed that $M$. incognita induced both SA-dependent and JA-dependent pathways in the roots of infected plants, which was confirmed by the high levels of mRNA transcripts of $P R-2, P R-3$ and $P R-5$ in the roots of $M$. incognita-infected plants (Hamamouch et al. 2011). The results of studies performed on peanut indicated that the defense responses in plants were highly conserved and involved cross talk between JA, SA and ethylene signaling cascades, as demonstrated by the upregulation of the gene encoding 6,7-dimethyl-8-ribityllumazine synthase, which catalyzes the penultimate step in the biosynthesis of riboflavin and may influence the cross talk among the ABA, SA, JA and ET signal cascade pathways in various biotic and abiotic stress environments (Tirumalaraju et al. 2011).

In addition, the involvement of transcription factors and gene expression regulators in the plant response to Meloidogyne infection was observed in several studies. Jammes et al. (2005), in their global analysis of A. thaliana infected with $M$. incognita, found that the successful establishment of this RKN was associated with the suppression of the plant defense mechanisms. In nematode-infected tissues, 17 of the 21 WRKY genes identified were downregulated, as was the case for other genes encoding other proteins involved in plant defense mechanisms, such as lipoxygenase or peroxidase (Jammes et al. 2005).

Among other proteins with very important roles in plants, RKNs interact with disease resistance proteins from the TIR-NBS class (Toll/interleukin-1 receptornucleotide-binding site) or the LRR (leucine-reach repeat) family proteins described in the A. thalianaM. incognita pathosystem (Fuller et al. 2007). The authors observed the upregulation of genes encoding these proteins in the later stages of infection in susceptible varieties.

Other studies indicated an involvement of cell wallmodifying proteins, auxin-related proteins and the ROSscavenging system in response to the invasion of 
Table 2 Host factors and their role in the plant-nematode interaction in monocotyledonous and dicotyledonous plants

\begin{tabular}{lllll}
\hline $\begin{array}{l}\text { Root-knot } \\
\text { nematode } \\
\text { species }\end{array}$ & Host species & $\begin{array}{l}\text { Analyzed genes/proteins (or group of } \\
\text { genes/proteins) }\end{array}$ & Changes in expression & Method Reference \\
\hline
\end{tabular}

Monocotyledonous plants

M. graminicola Oryza sativa

\author{
JiOsPR10, OsWRKY45, \\ OsPR1b, OsEin $2 b$ \\ OsZEP, OsNCED3, \\ OsLip9 \\ MAPK5a, MAPK6, MAPK20, \\ EDS1, PAD4, AOS2, ACS1, \\ ACO7, PR1a, PR10 \\ $M A P K 20$
}

PR1b, MAPK20, PAD4, NPR1, AOS2, ACO7, PR1b, WRKY13

MAPK6, RbohB, RAC1, PAL1, ICS1, EDS1, NPR1, EDS2, JAMYB, ECS1, EIN2, PR1a, PR1b, PR10, WRKY13, WRKY24

MAPK6, MAPK20, PAL1, ICS1, EDS1, PAD4, AOS2, JMT1, JAMYB, ACS1, ACO7, EIN2, PRla, PR1b, PR10, WRKY13, WRKY24 PAD4, NIH1

M. incognita

NIH1

MAPK5a, AOS2, PAD4, WRKY13

ZmPAL4

$\begin{array}{ccc}\text { M. arenaria } & \text { Zea mays } & \begin{array}{c}\text { PR3, PR4, PR5, peroxidase, } \\ \text { catalase or superoxide } \\ \text { dismutase }\end{array} \\ \text { M. incognita } \quad \text { Musa } & \text { LRR receptor-like serine/threonine } \\ & \text { acuminate } & \text { protein kinases, peroxidases, } \\ & \text { WRKY TFs, snakins } \\ & \text { MYB TF proteins, JA and ET } \\ & \text { signaling-related proteins and } \\ & \text { TFs, programmed cell } \\ & \text { death-related proteins }\end{array}$

Dicotyledonous plants

$\begin{array}{cc}\text { M.javanica } & \begin{array}{c}\text { Solanum } \\ \text { lycopersi- } \\ \text { cum }\end{array}\end{array}$

Downregulation in the early stage of infection in a susceptible variety

Upregulation in the early stage of infection in a susceptible variety

Upregulation in the early stage of infection in a susceptible variety

Downregulation in the early stage of infection in a susceptible variety

Downregulation in the later stage of infection in a susceptible variety

Upregulation in the early stage of infection in a resistant variety

Upregulation in the later stage of infection in a resistant variety

Downregulation in the early stage of infection in a susceptible variety

Upregulation in the early stage of infection in a susceptible variety

Downregulation in the early stage of infection in a susceptible variety

No expression in the highly susceptible variety, the highest level of expression in the most resistant variety

Downregulation in the early stage of infection in a resistant variety

Downregulation in the early stage of infection in a susceptible variety

Downregulation in both the early and later stages of infection in a susceptible variety

Downregulation in both the early and late stages
Real-time PCR Nahar et al. 2011

Real-time PCR Kyndt et al. 2012

Real-time PCR Kumari et al. 2016, 2017

Real-time PCR Nguyễn et al. 2014

$\begin{array}{lc}\begin{array}{l}\text { Semiquantitative } \\ \text { RT-PCR }\end{array} & \begin{array}{c}\text { Starr et al. } \\ 2014\end{array} \\ \text { Real-time PCR } & \begin{array}{r}\text { Przybylska } \\ \text { et al. 2018 }\end{array} \\ \text { NGS } & \begin{array}{r}\text { Castañeda } \\ \text { et al. } 2017\end{array}\end{array}$
Microarray Bar-Or et al. confirmed by 2005 real-time PCR


Table 2 (continued)

\begin{tabular}{llllll}
\hline $\begin{array}{l}\text { Root-knot } \\
\text { nematode } \\
\text { species }\end{array}$ & Host species & $\begin{array}{l}\text { Analyzed genes/proteins (or group of } \\
\text { genes/proteins) }\end{array}$ & Changes in expression & Method Reference \\
\hline
\end{tabular}

\begin{tabular}{|c|c|c|c|c|c|}
\hline & & Homeotic protein VAHOXI & $\begin{array}{l}\text { of infection in } \\
\text { susceptible varieties } \\
\text { Downregulation in the } \\
\text { early stages of infection } \\
\text { in susceptible varieties }\end{array}$ & & \\
\hline & & $W R K Y$, plant defensin & $\begin{array}{l}\text { Upregulation in both the } \\
\text { early and later stages of } \\
\text { infection in a } \\
\text { susceptible variety }\end{array}$ & & \\
\hline & & $\begin{array}{l}\text { Ethylene-responsive transcriptional } \\
\text { coactivator, hin1-like protein, gibberel- } \\
\text { lin 2-oxidase-like protein }\end{array}$ & $\begin{array}{l}\text { Upregulation in the later } \\
\text { stage of infection in a } \\
\text { susceptible variety }\end{array}$ & & \\
\hline \multirow[t]{11}{*}{ M. incognita } & \multirow[t]{11}{*}{$\begin{array}{l}\text { Solanum } \\
\text { lycopersi- } \\
\text { cum }\end{array}$} & $\begin{array}{l}\text { Transcription-related proteins, } \\
\text { signaling, defense-related } \\
\text { proteins } \\
\text { Transcription-related, signaling, } \\
\text { protein biosynthesis-related } \\
\text { proteins }\end{array}$ & $\begin{array}{l}\text { Upregulation in the early } \\
\text { stage of infection in a } \\
\text { resistant variety } \\
\text { Downregulation in the } \\
\text { early stage of infection } \\
\text { in a resistant variety }\end{array}$ & Microarray & $\begin{array}{l}\text { Bhattari et al. } \\
2008\end{array}$ \\
\hline & & $\begin{array}{l}\text { Transcription-factor-related, } \\
\text { signaling, cell-wall-related } \\
\text { proteins }\end{array}$ & $\begin{array}{l}\text { Upregulation in the early } \\
\text { stage of infection in a } \\
\text { susceptible variety }\end{array}$ & & \\
\hline & & $\begin{array}{l}\text { Transcription-related, protein } \\
\text { biosynthesis-related, signaling } \\
\text { proteins }\end{array}$ & $\begin{array}{l}\text { Downregulation in the } \\
\text { early stage of infection } \\
\text { in a susceptible variety }\end{array}$ & & \\
\hline & & $\begin{array}{l}\text { LeLOXA, LeLOXC, LeLOXD, } \\
\text { LeAOS1, LeAOS2, LeAOS3, } \\
\text { LeOpr3, LeJA3, LeDes, LeAOC, LeZIP, } \\
\text { LeCOI, LePrs, LeSR160 }\end{array}$ & $\begin{array}{l}\text { Gene expression } \\
\text { systemically activated } \\
\text { within 6-24 h and di- } \\
\text { minished over } 24-72 \mathrm{~h}\end{array}$ & Real-time PCR & $\begin{array}{l}\text { Fan et al. } \\
2015\end{array}$ \\
\hline & & PR1, PR2, PR5 & $\begin{array}{l}\text { Upregulation in the early } \\
\text { stage of infection in a } \\
\text { resistant variety }\end{array}$ & Real-time PCR & $\begin{array}{l}\text { Molinari } \\
\text { et al. } 2014\end{array}$ \\
\hline & & $\begin{array}{l}E F 1 \text {, collagen, } M A P 1 \text {, peptidase, } \\
\text { C-type lectin }\end{array}$ & $\begin{array}{l}\text { Downregulation in the } \\
\text { later stage of infection } \\
\text { in a susceptible variety }\end{array}$ & $\begin{array}{l}\text { NGS confirmed } \\
\text { by real-time } \\
\text { PCR }\end{array}$ & $\begin{array}{l}\text { Shukla et al. } \\
2018\end{array}$ \\
\hline & & MjNULG1a & $\begin{array}{l}\text { Upregulation in the later } \\
\text { stage of infection in a } \\
\text { susceptible variety }\end{array}$ & & \\
\hline & & UDP-glucosyltransferase & $\begin{array}{l}\text { Upregulation in the early } \\
\text { stage of infection and } \\
\text { downregulation in the } \\
\text { later stage of infection } \\
\text { in a susceptible variety }\end{array}$ & & \\
\hline & & Carboxylesterase & $\begin{array}{l}\text { Upregulation in the later } \\
\text { stage of infection in a } \\
\text { susceptible variety }\end{array}$ & & \\
\hline & & $\begin{array}{l}\text { Carbohydrate-binding module } \\
\text { family }\end{array}$ & $\begin{array}{l}\text { Downregulation in the } \\
\text { later stage of infection } \\
\text { in a susceptible } \\
\text { varietyss }\end{array}$ & & \\
\hline & & $\begin{array}{l}\text { Genes encoding aspartic, } \\
\text { metallo and serine } \\
\text { peptidases }\end{array}$ & $\begin{array}{l}\text { Upregulation in the early } \\
\text { stage of infection and } \\
\text { downregulation in the }\end{array}$ & & \\
\hline
\end{tabular}


Table 2 (continued)

\begin{tabular}{llllll}
\hline $\begin{array}{l}\text { Root-knot } \\
\text { nematode } \\
\text { species }\end{array}$ & Host species & $\begin{array}{l}\text { Analyzed genes/proteins (or group of } \\
\text { genes/proteins) }\end{array}$ & Changes in expression & Method Reference \\
\hline
\end{tabular}

Genes encoding various
peptidases
Genes encoding members of the
GH family, genes encoding
members of the PL family,
genes encoding aspartic and
cysteine peptidases
Cuticle collagen, tubulin
proteins

\section{IFA-1}

Calponin protein

Lipid transport proteins, cytosolic fatty acid-binding protein

Catalase

SOD

\section{M. incognita Arabidopsis thaliana}

\section{PR-1, PR-2, PR-3, PR-5}

LOB domain protein 41, wound-responsive family protein, lipid transfer protein, speckle-type POZ-related protein, zinc finger protein, kelch repeat-containing protein, histone $\mathrm{H} 3$, pathogenesis-related protein, signal peptide peptidase, photosystem I reaction center, leucine-rich repeat transmembrane protein kinase, arabinogalactan-protein, gibberellin-regulated protein 5 , senescence-associated-related protein, universal stress protein, auxin-responsive-related protein

Adenosine-deaminase family, UDP-glucuronosyltransferase family protein, glycosyl hydrolase family protein 5, F-box family protein, later stage of infection

in a susceptible variety

Upregulation in the later stage of infection in a susceptible variety

Upregulation in the early stage of infection in a resistant variety

Upregulation in a later stage of infection in a susceptible variety

Upregulation during all stages in a susceptible variety

Downregulation during all stages in a susceptible variety

Upregulation in the later stage of infection in a resistant variety

Upregulation in the early stage of infection and downregulation in the later stage of infection in a susceptible variety

Upregulation in a later stage of infection in a susceptible variety

Upregulation in the later stage of infection in a susceptible variety

Upregulation in the later stage of infection in a susceptible variety

Real-time PCR

Hamamouch et al. 2011

Microarray
confirmed by
real-time PCR

Fuller et al. 2007
Downregulation in the later stage of infection in a susceptible variety 
Table 2 (continued)

\begin{tabular}{lllll}
\hline $\begin{array}{l}\text { Root-knot } \\
\text { nematode } \\
\text { species }\end{array}$ & Host species & $\begin{array}{l}\text { Analyzed genes/proteins (or group of } \\
\text { genes/proteins) }\end{array}$ & Changes in expression & Method Reference \\
\hline
\end{tabular}

\begin{tabular}{|c|c|c|c|c|c|}
\hline & & $\begin{array}{l}\text { RNA-binding protein, germin-like } \\
\text { protein, ADP-ribosylation factor, cyto- } \\
\text { chrome P450 71B29, protein kinase } \\
\text { family protein, patatin, glutathione S- } \\
\text {-transferase, flavin-containing } \\
\text { monooxygenase family protein, glycine } \\
\text { cleavage system H protein 1, F-box } \\
\text { family protein, metal transporter, } \\
\text { CBL-interacting protein kinase 9, dis- } \\
\text { ease resistance protein, } \\
\text { polygalacturonase, allergen V5, } \\
\text { multicopper oxidase type I family, } \\
\text { MIF4G domain-containing protein, lec- } \\
\text { tin protein kinase family protein, gluta- } \\
\text { thione S-transferase, no apical meristem } \\
\text { family protein }\end{array}$ & & & \\
\hline & & $\begin{array}{l}\text { Major intrinsic family protein, } \\
\text { calcium-binding EF-hand, } \\
\text { lipoxygenase, ethylene-responsive } \\
\text { element-binding factor } 2 \text {, ammonium } \\
\text { transporter 1, glycosyl hydrolase family } \\
3 \text { protein }\end{array}$ & $\begin{array}{l}\text { Downregulation in the } \\
\text { later stage of infection } \\
\text { in a susceptible variety }\end{array}$ & $\begin{array}{l}\text { Microarray } \\
\text { confirmed by } \\
\text { real-time PCR }\end{array}$ & $\begin{array}{c}\text { Jammes et al. } \\
2005\end{array}$ \\
\hline & & $\begin{array}{l}\text { Pectate lyase family protein, expansin, } \\
\text { beta-expansin, glycoside hydrolase } \\
\text { family } 28 \text { protein, } 3^{\prime} \text { exoribonuclease } \\
\text { family domain } 1 \text {-containing protein, } \\
\text { sulfate transporter, } \\
\text { microtubule-associated protein, elonga- } \\
\text { tion factor } 1 \text {-alpha, formin homology } \\
\text { domain-containing family, amino acid } \\
\text { transporter family protein, MYB family } \\
\text { transcription factor, } \\
\text { phosphate-responsive } 1 \text { family protein, } \\
\text { gibberellin-regulated protein } 4 \text {, pyruvate } \\
\text { decarboxylase }\end{array}$ & $\begin{array}{l}\text { Upregulation in the later } \\
\text { stage of infection in a } \\
\text { susceptible variety }\end{array}$ & & \\
\hline & & $\begin{array}{l}\text { miR157d, miR159a, miR159c, miR156h, } \\
\text { miR167d, miR390a/b, miR398a, } \\
\text { miR398b/c, miR408, miR831, } \\
\text { miR833b, miR2111a-3p, miR2934-5p } \\
\text { miR163, miR164c, miR319c, miR399b/c, } \\
\text { miR822, miR861-5p }\end{array}$ & $\begin{array}{l}\text { Upregulation in the later } \\
\text { stage of infection in a } \\
\text { susceptible variety } \\
\text { Downregulation in the } \\
\text { later stage of infection } \\
\text { in a susceptible variety }\end{array}$ & $\begin{array}{l}\text { miRNA } \\
\text { sequencing }\end{array}$ & $\begin{array}{l}\text { Medina et al. } \\
2017\end{array}$ \\
\hline \multirow[t]{2}{*}{ M. arenaria } & $\begin{array}{l}\text { Arachis } \\
\quad \text { hypogaea }\end{array}$ & $\begin{array}{l}\text { PR protein, patatin, USP, MFS transporter, } \\
\text { transmembrane transporter, expansin } \\
\text { B1 } \\
\text { Catalase, Aux/IAA TF, XET, tetraspanin-- } \\
\text { LEL-like, integrin-like, phi-1 }\end{array}$ & $\begin{array}{l}\text { Upregulation in all stages } \\
\text { of infection in a } \\
\text { resistant variety } \\
\text { Upregulation in all stages } \\
\text { of infection in a } \\
\text { susceptible variety }\end{array}$ & $\begin{array}{l}\text { SSH confirmed } \\
\text { by real-time } \\
\text { PCR }\end{array}$ & $\begin{array}{r}\text { Tirumalaraju } \\
\text { et al. } 2011\end{array}$ \\
\hline & & Defense-responsive genes & $\begin{array}{l}\text { Upregulation in a resistant } \\
\text { variety and } \\
\text { downregulation or } \\
\text { unchanged in a } \\
\text { susceptible variety }\end{array}$ & NGS & $\begin{array}{l}\text { Clevenger } \\
\text { et al. } 2017\end{array}$ \\
\hline
\end{tabular}


Table 2 (continued)

\begin{tabular}{llllll}
\hline $\begin{array}{l}\text { Root-knot } \\
\text { nematode } \\
\text { species }\end{array}$ & Host species & $\begin{array}{l}\text { Analyzed genes/proteins (or group of } \\
\text { genes/proteins) }\end{array}$ & Changes in expression & Method Reference \\
\hline
\end{tabular}

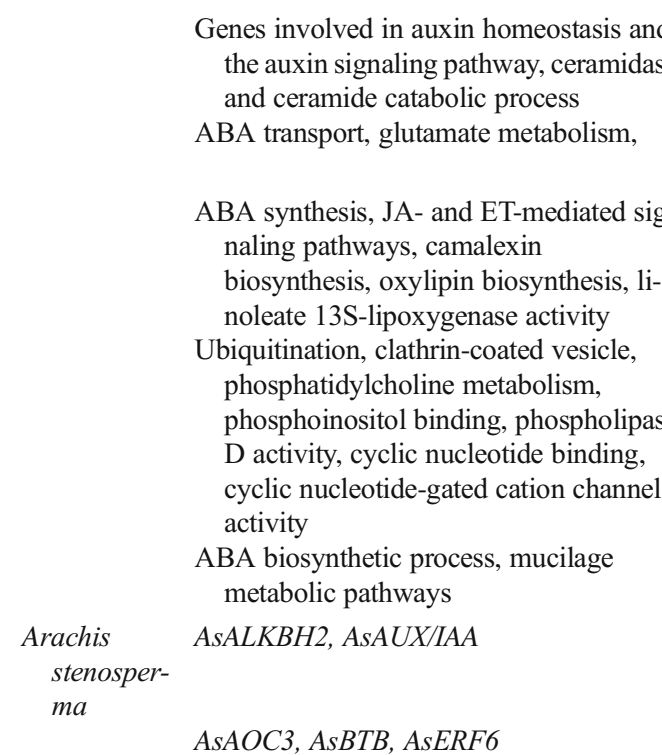

AsGH3.1, AsSLP

AsSAG, AsTIR-NBS-LRR, AsSAG
Downregulation in both

varieties

Upregulation in a susceptible variety

Downregulation in a susceptible variety

Upregulation in a resistant variety

Downregulation in a resistant variety

Downregulation in the later stages of infection in a resistant variety

Downregulation in early and later stages of infection in a resistant variety

Downregulation in the early stage of infection in a resistant variety

Downregulation in the early stage of infection and upregulation in the later stage of infection in a resistant variety

AsAraH8, AsATPase $\alpha$, AsBap, AsCOX1, Upregulation during all AsCWAH, AsCWAH2, AsMYB25, AsWRKY49

AsTAT

AsBger, AsCHI2, AsCOX1, AsIOMT, AsUreD

M. incognita Glycine max LOX1, OPR2/OPR3

PECT, CCOA-OMT, C3H, CDKB2, FSH

AOS, CELL stages of infection in a resistant variety

Upregulation in the early stage of infection in a resistant variety

Upregulation in the later stage of infection in a resistant variety

Upregulation in the early stage of infection and downregulation in the later stage of infection in a susceptible variety

Upregulation in all stages of infection in a susceptible variety

Downregulation in all stages of infection in a susceptible variety
NGS confirmed by real-time PCR

Guimaraes et al. 2015 $\begin{array}{lr}\text { Microarray } & \text { Ibrachim } \\ \text { confirmed by } & \text { et al. } 2011\end{array}$ real-time PCR 
Table 2 (continued)

\begin{tabular}{|c|c|c|c|c|c|}
\hline $\begin{array}{l}\text { Root-knot } \\
\text { nematode } \\
\text { species }\end{array}$ & Host species & $\begin{array}{l}\text { Analyzed genes/proteins (or group of } \\
\text { genes/proteins) }\end{array}$ & Changes in expression & Method & Reference \\
\hline & & $A O C$ & $\begin{array}{l}\text { Downregulation in the } \\
\text { early stage of infection } \\
\text { in a susceptible variety }\end{array}$ & & \\
\hline & & CYCD3 & $\begin{array}{l}\text { Downregulation in the } \\
\text { later stage of infection } \\
\text { in a susceptible variety }\end{array}$ & & \\
\hline M. incognita & Glycine max & Chitinase & $\begin{array}{l}\text { Upregulation in the later } \\
\text { stage of infection in a } \\
\text { resistant variety }\end{array}$ & $\begin{array}{l}\text { Chitinase activity } \\
\text { assay }\end{array}$ & $\begin{array}{c}\text { Qtu et al. } \\
1997\end{array}$ \\
\hline \multirow[t]{7}{*}{ M. incognita } & \multirow[t]{2}{*}{$\begin{array}{l}\text { Vigna } \\
\text { unguicul- } \\
\text { ata }\end{array}$} & $\begin{array}{l}\text { 26S proteasome, aldo-keto reductase, } \\
\text { spermidine synthase, patatin }\end{array}$ & $\begin{array}{l}\text { Downregulation in the } \\
\text { early stage of infection } \\
\text { and upregulation in later } \\
\text { stages of infection in a } \\
\text { resistant variety }\end{array}$ & \multirow[t]{2}{*}{$\begin{array}{l}\text { 2-DE confirmed } \\
\text { by real-time } \\
\text { PCR }\end{array}$} & \multirow[t]{2}{*}{$\begin{array}{l}\text { Villeth et al. } \\
2015\end{array}$} \\
\hline & & $\begin{array}{l}\text { 20S proteasome, nitrile-specifier protein } 5 \text {, } \\
\text { disease resistance protein RPP13, } \\
\text { hydroxyacid oxidase, isopropylmalate } \\
\text { dehydrogenase }\end{array}$ & $\begin{array}{l}\text { Upregulation in the later } \\
\text { stages of infection in a } \\
\text { resistant variety }\end{array}$ & & \\
\hline & \multirow[t]{5}{*}{$\begin{array}{l}\text { Nicotiana } \\
\text { tabacum }\end{array}$} & $\begin{array}{l}\text { PMEU1, GUN9, BGL, PGLR4, E1312, } \\
\quad \text { Y5487, AUX/IAA, LAX5 }\end{array}$ & $\begin{array}{l}\text { Downregulation in a } \\
\text { resistant variety and } \\
\text { upregulation in a } \\
\text { susceptible variety }\end{array}$ & \multirow[t]{5}{*}{$\begin{array}{l}\text { NGS confirmed } \\
\text { by real-time } \\
\text { PCR }\end{array}$} & \multirow[t]{5}{*}{$\begin{array}{l}\text { Xing et al. } \\
2017\end{array}$} \\
\hline & & LRX4, NEK2, PRB1, PER11 & $\begin{array}{l}\text { Downregulation in a } \\
\text { resistant variety }\end{array}$ & & \\
\hline & & Kinase CLV1 & $\begin{array}{l}\text { Downregulation in both } \\
\text { varieties }\end{array}$ & & \\
\hline & & GH3, TGA21, GST23 & $\begin{array}{l}\text { Upregulation in a resistant } \\
\text { variety and } \\
\text { downregulation in a } \\
\text { susceptible variety }\end{array}$ & & \\
\hline & & $P R B 1$ & $\begin{array}{l}\text { Upregulation in a resistant } \\
\text { variety }\end{array}$ & & \\
\hline \multirow[t]{3}{*}{ M. incognita } & \multirow[t]{3}{*}{$\begin{array}{l}\text { Medicago } \\
\text { sativa }\end{array}$} & $\begin{array}{l}\text { NB-ARC domain disease resistance } \\
\text { protein, lipid transfer protein, } \\
\text { calcium-binding EF-hand-like protein, } \\
\text { cysteine-rich receptor-kinase-like } \\
\text { protein, patatin-like phospholipase, } \\
\text { transcription factor bHLH122-like pro- } \\
\text { tein }\end{array}$ & $\begin{array}{l}\text { Downregulation in a } \\
\text { susceptible variety }\end{array}$ & \multirow[t]{3}{*}{$\begin{array}{l}\text { NGS confirmed } \\
\text { by real-time } \\
\text { PCR }\end{array}$} & \multirow[t]{3}{*}{$\begin{array}{l}\text { Postnikova } \\
\text { et al. } 2015\end{array}$} \\
\hline & & $\begin{array}{l}\text { Matrixin family protein, flavonol } \\
\text { synthase/flavanone 3-hydroxylase, } \\
\text { transmembrane protein, heat shock } \\
\text { cognate } 70 \mathrm{kDa} \text { protein, F-ox/FBD-like } \\
\text { domain protein, }\end{array}$ & $\begin{array}{l}\text { Upregulation in a } \\
\text { susceptible variety }\end{array}$ & & \\
\hline & & $\begin{array}{l}\text { Matrixin family protein, glutamate } \\
\text { receptor 3.3, organelle transcript } \\
\text { processing protein, heat shock cognate } \\
70 \mathrm{kDa} \text { protein, } \\
\text { endonuclease/exonuclease/phosphatase } \\
\text { family protein, F-box/RNI/FBD-like } \\
\text { domain protein, Harpin-inducing pro- } \\
\text { tein 1-like protein }\end{array}$ & $\begin{array}{l}\text { Downregulation in a } \\
\text { resistant variety }\end{array}$ & & \\
\hline
\end{tabular}


Table 2 (continued)

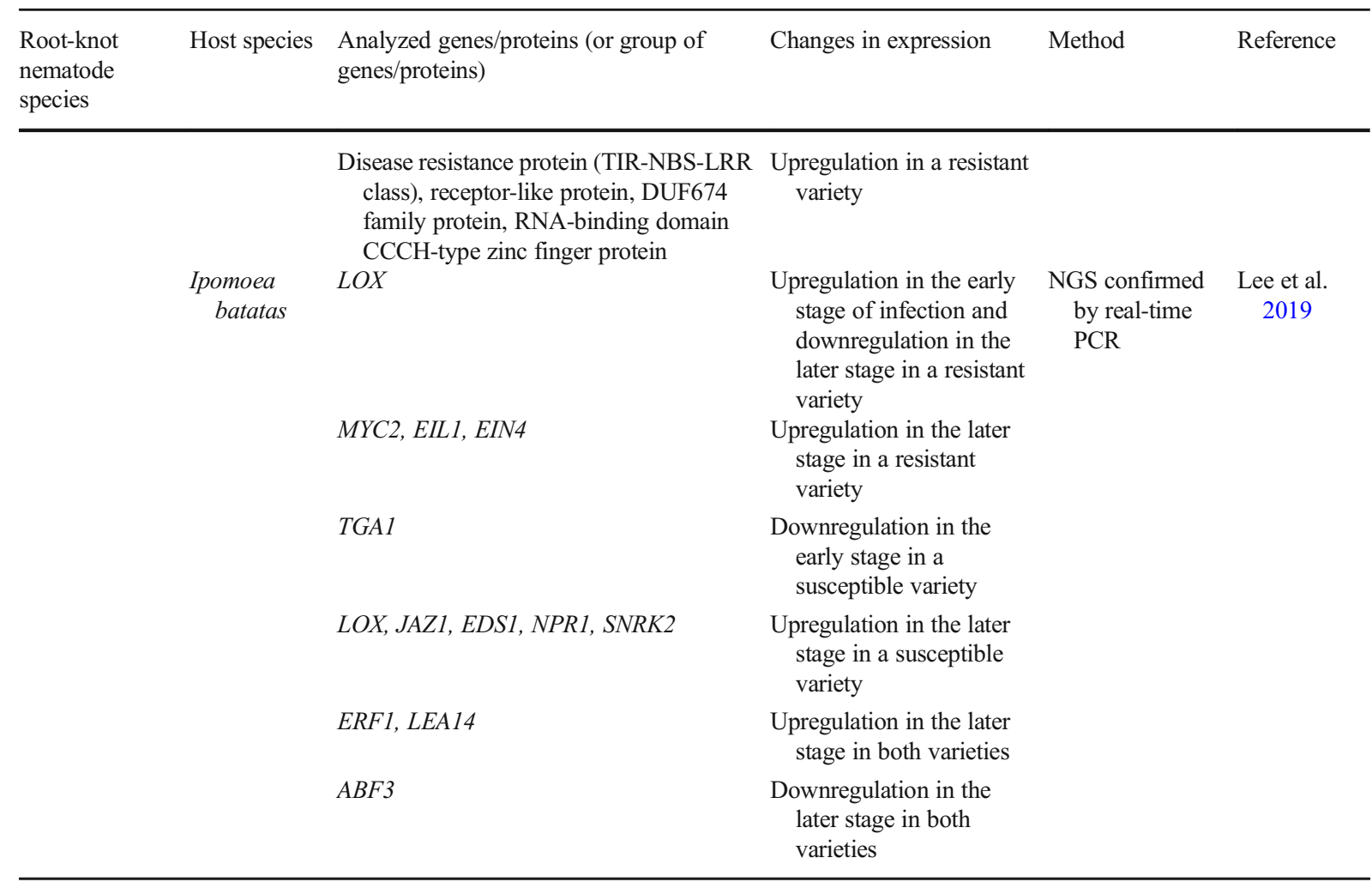

nematodes in tobacco (N. tabacum) (Xing et al. 2017). In addition, the results obtained for coffee suggested that the genes related to cell death, cell wall modification, oxidative burst, gene expression regulation and defense played a role in coffee plants as 'RKN-responsive' genes. Their common regulation in compatible and incompatible interactions suggested that their expression overlaps in the PTI and ETI responses (Albuquerque et al. 2017).

\section{Incompatible interactions}

Many studies have attempted to explain the mechanism of host resistance to RKN infection. The data from the transcriptome profiling of a resistant variety of cucumber (Cucumis metuliferus) infected with $M$. incognita suggested an important role for proteins involved in the first layer of plant defense (Ling et al. 2017). The authors discovered that the PAMP-associated genes, including $B A K 1$ and $A D F s$, may have been important for the resistance of this plant to RKNs that similarly utilize two pathogen-related signal genes: $M P K 3$ and MPK6.
On the other hand, some authors investigated the role of JA, SA and ET signaling pathways. Research conducted on the tomato-M. incognita model showed that the components of ET, ABA and SA signaling were differentially regulated during both the susceptible and resistant responses (Clevenger et al. 2017). In addition, the authors observed that in resistant varieties of peanut, the number of induced proteins involved in plant stress and defense responses was comparatively higher than that in the susceptible varieties, including putative PR proteins, patatin-like proteins and other stress-related proteins (Tirumalaraju et al. 2011). Guimaraes et al. (2015) analyzed $M$. arenaria resistance in wild peanut (Arachis stenosperma) plants and found that both JAdependent and SA-dependent defense genes and their regulators were triggered in wild peanut roots infected with M. arenaria. Additionally, Qtu et al. (1997) described an important role of chitinases during the M. incognita infection of a resistant variety of soybean, which may indicate an important role of both the JA and SA pathways in the soybean resistance response. On the other hand, in the tomato-M. javanica and tomatoM. incognita pathosystems, the authors observed that a 
tomato mutant, which does not accumulate JA after wounding, did not exhibit reduced susceptibility, thus indicating that nematode susceptibility does not depend on JA biosynthesis (Bhattarai et al. 2008).

Other tomato genes with upregulated expression during incompatible interactions are those encoding the defensin protein and subtilisin-like protease, leading to the production of phytoalexins and stress-induced proteolysis (Shukla et al. 2018). Studies performed on coffee indicated that host resistance to M. exigua was not only due to the HR but also due to a set of defense responses that were both constitutive and induced after nematode penetration, that resulted in the inhibition of feeding site formation, and that provoked J2 migration or inhibited nematode development and reproduction (Silva et al. 2013). Moreover, the genes encoding LRR and TIR-NBS class proteins were upregulated in a resistant variety of alfalfa infected with $M$. incognita (Postnikova et al. 2015). Alternatively, Clevenger et al. (2017), in a study on wild peanut plants resistant to $M$. arenaria, reported the downregulation of these genes in the early stage of infection but upregulation during later stages of infection.

Additionally, the transcriptome analysis of two alfalfa (Medicago sativa) cultivars that were sensitive and resistant to $M$. incognita infection revealed nearly a thousand differentially expressed genes that were presumably involved in basal defense responses and in resistance pathways and revealed a number of transcripts potentially associated with resistance to RKNs (Postnikova et al. 2015). Another genome-wide transcriptome analysis with susceptible and resistant varieties was performed in sweet potato (Ipomoea batatas) infected with $M$. incognita. The authors indicated an increase in the activity of genes involved in defense signaling, including genes encoding transcription factors as well as these associated with JA, SA, ET and ABA pathways, which were upregulated in a resistant variety under RKN treatment (Lee et al. 2019).

Moreover, research conducted on A. thaliana suggested a role for the miRNA family, designated miR159, in the formation of galls during the plant response to $M$. incognita infection. A strong resistance to this nematode was observed in the miR159abc triple Arabidopsis mutant. The miR159 family is known to regulate MYB transcription factors implicated in the ABA-mediated response and in interactions with other transcription factors (Medina et al. 2017).
The results of studies performed on dicotyledonous plants are summarized in Table 2.

Concluding remarks

Effectors of RKNs are multifunctional proteins that are involved in interactions with mono- and dicotyledonous hosts, and they are able to manipulate plant metabolism on many different levels. Most of the described effectors were analyzed, and their modes of action were studied for one species of nematode in which they are expressed. However, one of the described effectors (Msp18) is conserved among many nematode species, including M. hapla, M. floridensis, M. incognita, $M$. javanica and M. graminicola. Effectors encoded by RKNs with a broad spectrum of host plant species, such as $M$. incognita, were reported to play similar roles as the effectors encoded by $M$. graminicola, whose main crop host is rice.

The research conducted so far has shown that there are some differences between the responses of monocotyledonous and dicotyledonous plants to RKN infection. However, it is difficult to say whether these are real differences or simply a highly unbalanced number of publications on the reaction of monocotyledonous and dicotyledonous plants to RKN infection. The likely cause of this imbalance is the fact that more dicotyledonous than monocotyledonous plants have been observed to be RKN hosts (CABI 2020). Most studies conducted on monocotyledonous plants have suggested a role for both the JA/ET- and SA-mediated pathways in the plant response during the early stages of infection, but these responses may be suppressed during the later stages in compatible interactions in contrast to resistant varieties where the changes in expression of genes encoding proteins involved in these pathways can still be observed. This statement is true for RKNs with broad host ranges, such as $M$. incognita and $M$. arenaria, as well as for monocot-specific $M$. graminicola species. In studies on dicotyledonous plants, the authors primarily indicate the role of the JA/ET-mediated pathways in compatible interactions, while the SA-mediated pathway seems to play a supporting role, primarily in resistant varieties. Additional differences concerning the expression of genes encoding transcription factors were also observed as well as in the expression level of ABAmediated pathway marker genes, which were significantly upregulated in susceptible varieties of rice infected by M. graminicola, while in peanut plants infected by 
M. arenaria, the genes associated with ABA synthesis were downregulated.

The plant response to RKN infection is very extensive, occurs on multiple levels and involves the engagement of many different pathways. Many nematode species are able to overcome all barriers, including all activated defense mechanisms in both mono- and dicotyledonous plant species. When the infection process is successfully established, plant metabolism is reorganized at all possible levels, beginning from epigenetic changes (miRNA) to structural and morphological modifications (giant cells).

Future challenges and research directions

Although knowledge on the processes involved in RKN-plant interactions has significantly increased in recent years, there are still important aspects of these interactions that have not yet been thoroughly investigated. This category includes the regulation of signaling pathways and the involvement of posttranslational modifications, e.g., phosphorylation, in plant-Meloidogyne interactions, as has been studied for few nematode species (Hewezi 2015). Among other factors that should be elucidated further in future studies is the role of epigenetic changes in plant resistance/susceptibility to the infection process, as shown for cyst nematodes and soybean (Li et al. 2012). Another promising research direction is the induction of systemic resistance in host plants. There are many studies on the possible induction of systemic resistance by abiotic agents, such as BTH (benzo[1,2,3]thiadiazole-7-carbothioic acid S-methyl ester) and its derivatives, BABA ( $\beta$-aminobutyric acid) or MeJa (methyl jasmonate) (Frackowiak et al. 2019; Fujimoto et al. 2011; Mutar and Fattah 2013; Veronico et al. 2018) as well as by microorganisms such as bacteria or fungi (El-Fattah and Sikora 2007; Siddiqui and Shaukat 2004; Vos et al. 2013). This topic, however, still has great investigation potential in nematode studies.

Moreover, a broader spectrum of data concerning the molecular mechanisms of plant immunity might be essential to develop resistant varieties of economically important RKN hosts.

It is very likely that in plant-Meloidogyne interactions, many other factors may play roles that have not yet been investigated in detail in this pathosystem. Studies conducted in recent years have provided substantial evidence for the important role of symbiotic microorganisms associated with various pests, especially insects, in the modulation of the outcomes of pestplant interactions (Wielkopolan et al. 2018). Research on nematode-associated microbiota has also been performed for some nematode species, including M. incognita, and the microbes associated with their different life stages (Cao et al. 2015; Elhady et al. 2017), but for the majority of the Meloidogyne species, the role of symbionts has been subjected to limited analyses. However, this aspect might contribute to an enhanced understanding of the parasitism process involving RKNs in their host plants.

Acknowledgments This study was supported by the Polish National Science Center grant UMO-2014/13/N/NZ9/00703.

Open Access This article is licensed under a Creative Commons Attribution 4.0 International License, which permits use, sharing, adaptation, distribution and reproduction in any medium or format, as long as you give appropriate credit to the original author(s) and the source, provide a link to the Creative Commons licence, and indicate if changes were made. The images or other third party material in this article are included in the article's Creative Commons licence, unless indicated otherwise in a credit line to the material. If material is not included in the article's Creative Commons licence and your intended use is not permitted by statutory regulation or exceeds the permitted use, you will need to obtain permission directly from the copyright holder. To view a copy of this licence, visit http://creativecommons.org/licenses/by/4.0/.

\section{References}

A2 List of pests recommended for regulation as quarantine pests (2017). Accessed 2018-07-19

Albuquerque EV, Petitot A-S, da Silva JP, Grossi-de-Sa MF, Fernandez D (2017) Early responses of coffee immunityrelated genes to root-knot nematode infection. Physiol Mol Plant Pathol 100:142-150

Barbary A, Djian-Caporalino C, Palloix A, Castagnone-Sereno P (2015) Host genetic resistance to root-knot nematodes, Meloidogyne spp., in Solanaceae: from genes to the field. Pest Manag Sci 71:1591-1598

Bar-Or C, Kapulnik Y, Koltai H (2005) A broad characterization of the transcriptional profile of the compatible tomato response to the plant parasitic root knot nematode Meloidogyne javanica. European Journal of Plant Pathology 111:181

Bhattarai KK, Xie Q-G, Mantelin S, Bishnoi U, Girke T, Navarre DA, Kaloshian I (2008) Tomato susceptibility to root-knot nematodes requires an intact jasmonic acid signaling pathway. Molecular plant-microbe interactions 21:1205-1214

Bradley DJ, Kjellbom P, Lamb CJ (1992) Elicitor-and woundinduced oxidative cross-linking of a proline-rich plant cell wall protein: a novel, rapid defense response. Cell 70:21-30 
CABI (2020) Invasive species compendium https://www.cabi. org/ISC

Caillaud M-C, Dubreuil G, Quentin M, Perfus-Barbeoch L, Lecomte P, de Almeida Engler J, Abad P, Rosso MN, Favery B (2008) Root-knot nematodes manipulate plant cell functions during a compatible interaction. J Plant Physiol 165:104-113

Cao Y, Tian B, Ji X, Shang S, Lu C, Zhang K (2015) Associated bacteria of different life stages of using pyrosequencingbased analysis. J Basic Microbiol 55(8):950-960

Castaneda NEN et al (2017) Gene expression analysis in Musa acuminata during compatible interactions with Meloidogyne incognita. Ann Bot 119(5):915-930

Chen J, Lin B, Huang Q, Hu L, Zhuo K, Liao J (2017) A novel Meloidogyne graminicola effector, MgGPP, is secreted into host cells and undergoes glycosylation in concert with proteolysis to suppress plant defenses and promote parasitism. PLoS pathogens 13:e1006301

Chen J, Hu L, Sun L, Lin B, Huang K, Zhuo K, Liao J (2018) A novel Meloidogyne graminicola effector, MgMO237, interacts with multiple host defence-related proteins to manipulate plant basal immunity and promote parasitism. Molecular Plant Pathology

Clevenger J et al (2017) Gene expression profiling describes the genetic regulation of Meloidogyne arenaria resistance in Arachis hypogaea and reveals a candidate gene for resistance. Scientific Reports 7:1317

Corbett BP, Jia L, Sayler RJ, Arevalo-Soliz LM, Goggin F (2011) The effects of root-knot nematode infection and mi-mediated nematode resistance in tomato on plant fitness. Journal of Nematology 43:82

Davis EL, Hussey RS, Mitchum MG, Baum TJ (2008) Parasitism proteins in nematode-plant interactions. Current opinion in plant biology 11:360-366

Djian-Caporalino C et al. (2007) Root-knot nematode (Meloidogyne spp.) me resistance genes in pepper (Capsicum annuum L.) are clustered on the P9 chromosome. Theoretical and Applied Genetics 114:473-486

Doyle EA, Lambert KN (2003) Meloidogyne javanica chorismate mutase 1 alters plant cell development. Mol Plant-Microbe Interact 16:123-131

Dropkin V (1969) The necrotic reaction of tomatoes and other hosts resistant to Meloidogyne: reversal by temperature. Phytopathology 59:1632-1637

Dubreuil G, Magliano M, Dubrana MP, Lozano J, Lecomte P, Favery B, Abad P, Rosso MN (2009) Tobacco rattle virus mediates gene silencing in a plant parasitic root-knot nematode. J Exp Bot 60:4041-4050

El-Fattah ADA, Sikora AR (2007) Induced resistance by the mutualistic endophyte, Fusarium oxysporum strain 162, toward Meloidogyne incognita on tomato. Biocontrol Sci Technol 17:969-975

El-Sappah AH et al. (2019) Tomato natural resistance genes in controlling the root-knot. Nematode Genes 10:925

Elhady A, Giné A, Topalovic O, Jacquiod S, Sørensen SJ, Sorribas FJ, Heuer H, Castagnone-Sereno P (2017) Microbiomes associated with infective stages of root-knot and lesion nematodes in soil. PLOS ONE 12(5):e0177145

Endler A, Persson S (2011) Cellulose synthases and synthesis in Arabidopsis. Molecular Plant 4:199-211
EPPO (2016) EPPO standard PM 7/41 (3) Meloidogyne chitwoodi and Meloidogyne fallax. EPPO Bulletin 46:171-189

Fan J, Hu C, Zhang L, Li Z, Zhao F, Wang S (2015) Jasmonic acid mediates tomato's response to root knot nematodes. J Plant Growth Regul 34:196-205

Flor HH (1971) Current status of the gene-for-gene concept. Annu Rev Phytopathol 9:275-296

Frąckowiak P, Pospieszny H, Smiglak M, Obrępalska-Stęplowska A (2019) Assessment of the efficacy and mode of action of Benzo (1, 2, 3)-Thiadiazole-7-Carbothioic acid S-methyl Ester $(\mathrm{BTH})$ and its derivatives in plant protection against viral disease. Int J Mol Sci 20:1598

Fujimoto T, Tomitaka Y, Abe H, Tsuda S, Futai K, Mizukubo T (2011) Expression profile of jasmonic acid-induced genes and the induced resistance against the root-knot nematode (Meloidogyne incognita) in tomato plants (Solanum lycopersicum) after foliar treatment with methyl jasmonate. J Plant Physiol 168:1084-1097

Fuller VL, Lilley CJ, Atkinson HJ, Urwin PE (2007) Differential gene expression in Arabidopsis following infection by plantparasitic nematodes Meloidogyne incognita and Heterodera schachtii Mol Plant Pathol 8:595-609

Gao X, Starr J, Göbel C, Engelberth J, Feussner I, Tumlinson J, Kolomiets M (2008) Maize 9-lipoxygenase ZmLOX3 controls development, root-specific expression of defense genes, and resistance to root-knot nematodes. Mol Plant-Microbe Interact 21:98-109

Gheysen G, Fenoll C (2002) Gene expression in nematode feeding sites. Annual review of phytopathology 40:191-219

Gleason C, Polzin F, Habash SS, Zhang L, Utermark J, Grundler FM, Elashry A (2017) Identification of two Meloidogyne hapla genes and an investigation of their roles in the plantnematode interaction Molecular plant-microbe interactions 30:101-112

Grossi-de-Sa M et al. (2019) Rice susceptibility to root-knot nematodes is enhanced by the Meloidogyne incognita MSP18 effector gene Planta:1-13

Guimaraes PM et al. (2015) Root transcriptome analysis of wild peanut reveals candidate genes for nematode resistance. PloS one 10:e0140937

Hamamouch N, Li C, Seo PJ, Park C-M, Davis EL (2011) Expression of Arabidopsis pathogenesis-related genes during nematode infection. Mol Plant Pathol 12:355-364

Hewezi T (2015) Cellular signaling pathways and posttranslational modifications mediated by nematode effector proteins Plant Physiol 169:1018-1026

Holbein J, Franke RB, Marhavý P, Fujita S, Górecka M, Sobczak M, Geldner N, Schreiber L, Grundler FMW, Siddique S (2019) Root endodermal barrier system contributes to defence against plant-parasitic cyst and root-knot nematodes. Plant J 100:221-236

Huang G, Gao B, Maier T, Allen R, Davis EL, Baum TJ, Hussey RS (2003) A profile of putative parasitism genes expressed in the esophageal gland cells of the root-knot nematode Meloidogyne incognita. Molecular Plant-Microbe Interactions 16:376-381

Huang G, Dong R, Allen R, Davis EL, Baum TJ, Hussey RS (2005) Developmental expression and molecular analysis of two Meloidogyne incognita pectate lyase genes. Int J Parasitol 35:685-692 
Hückelhoven R (2007) Cell wall-associated mechanisms of disease resistance and susceptibility. Annu Rev Phytopathol 45: 101-127

Hussey RS (1989) Disease-inducing secretions of plant-parasitic nematodes. Annu Rev Phytopathol 27:123-141

Ibrahim HM, Hosseini P, Alkharouf NW, Hussein EH, Abd El Kader Y, Aly MA, Matthews BF (2011) Analysis of Gene expression in soybean (Glycine max) roots in response to the root knot nematode Meloidogyne incognita using microarrays and KEGG pathways. BMC Genomics 12:220

Jammes F, Lecomte P, Almeida-Engler J, Bitton F, MartinMagniette ML, Renou JP, Abad P, Favery B (2005) Genome-wide expression profiling of the host response to root-knot nematode infection in Arabidopsis. Plant J 44:447458

Jaouannet M, Magliano M, Arguel MJ, Gourgues M, Evangelisti E, Abad P, Rosso M-N (2013) The root-knot nematode calreticulin Mi-CRT is a key effector in plant defense suppression. Molecular Plant-Microbe Interactions 26:97-105

Jaubert S, Laffaire J-B, Abad P, Rosso M-N (2002) A polygalacturonase of animal origin isolated from the rootknot nematode Meloidogyne incognita. FEBS letters 522: $109-112$

Jones M (1981) Host cell responses to endoparasitic nematode attack: structure and function of giant cells and syncytia. Annals of Applied Biology 97:353-372

Jones JD, Dangl JL (2006) The plant immune system. Nature 444: 323

Jones MGK, Goto DB (2011) Root-knot nematodes and Giant cells. In: Jones J, Gheysen G, Fenoll C (eds) Genomics and molecular genetics of plant-nematode interactions. Springer Netherlands, Dordrecht, pp 83-100. https://doi.org/10.1007 /978-94-007-0434-3_5

Kaloshian I, Teixeira M ${ }^{-}$(2019) Advances in plant- nematode interactions with emphasis on the notorious nematode genus. Meloidogyne Phytopathology 109:1988-1996

Kaloshian I, Desmond OJ, Atamian HS (2011) Disease resistancegenes and defense responses during incompatible interactions. Genomics and Molecular Genetics of PlantNematode Interactions. Springer, In, pp 309-324

Kiewnick S, Dessimoz M, Franck L (2009) Effects of the Mi-1 and the $\mathrm{N}$ root-knot nematode-resistance gene on infection and reproduction of Meloidogyne enterolobii on tomato and pepper cultivars. J Nematol 41:134

Kumari C, Dutta TK, Banakar P, Rao U (2016) Comparing the defence-related gene expression changes upon root-knot nematode attack in susceptible versus resistant cultivars of rice Sci Rep 6:22846

Kumari C, Dutta TK, Gahoi S, Rao U (2017) An insight into the expression profile of defence-related genes in compatible and incompatible Oryza sativa-Meloidogyne graminicola interaction. Indian Journal of Genetics and Plant Breeding (The) 77: $42-50$

Kyndt T, Nahar K, Haegeman A, De Vleesschauwer D, Höfte M, Gheysen G (2012) Comparing systemic defence-related gene expression changes upon migratory and sedentary nematode attack in rice. Plant biology 14:73-82

Kyndt T, Nahar K, Haeck A, Verbeek R, Demeestere K, Gheysen G (2017) Interplay between carotenoids, abscisic acid and jasmonate guides the compatible rice-Meloidogyne graminicola interaction. Front Plant Sci 8:951
Lee IH, Shim D, Jeong JC, Sung YW, Nam KJ, Yang JW, Ha J, Lee JJ, Kim YH (2019) Transcriptome analysis of root-knot nematode (Meloidogyne incognita)-resistant and susceptible sweetpotato cultivars. Planta 249:431-444

Leelarasamee N, Zhang L, Gleason C (2018) The root-knot nematode effector MiPFN3 disrupts plant actin filaments and promotes parasitism. PLoS Pathog 14:e1006947

Li X, Wang X, Zhang S, Liu D, Duan Y, Dong W (2012) Identification of soybean microRNAs involved in soybean cyst nematode infection by deep sequencing. PloS one 7: e39650

Lin B, Zhuo K, Chen S, Hu L, Sun L, Wang X, Zhang LH, Liao J (2016) A novel nematode effector suppresses plant immunity by activating host reactive oxygen species-scavenging system. New Phytol 209:1159-1173

Ling J, Mao Z, Zhai M, Zeng F, Yang Y, Xie B (2017) Transcriptome profiling of Cucumis metuliferus infected by Meloidogyne incognita provides new insights into putative defense regulatory network in Cucurbitaceae. Sci Rep 7:3544

Malinovsky FG, Fangel JU, Willats WG (2014) The role of the cell wall in plant immunity. Front Plant Sci 5:178

Manosalva P et al. (2015) Conserved nematode signalling molecules elicit plant defenses and pathogen resistance. Nat Commun 6:7795

Medina C, da Rocha M, Magliano M, Ratpopoulo A, Revel B, Marteu N, Magnone V, Lebrigand K, Cabrera J, Barcala M, Silva AC, Millar A, Escobar C, Abad P, Favery B, JaubertPossamai S (2017) Characterization of microRNAs from Arabidopsis galls highlights a role for miR159 in the plant response to the root-knot nematode Meloidogyne incognita. New Phytol 216:882-896

Mejias J, Truong NM, Abad P, Favery B, Quentin M (2019) Plant proteins and processes targeted by parasitic nematode effectors. Front Plant Sci 10

Mendy B et al. (2017) Arabidopsis leucine-rich repeat receptorlike kinase NILR1 is required for induction of innate immunity to parasitic nematodes. PLoS pathogens 13:e1006284

Moens M, Perry RN, Starr JL (2009) Meloidogyne species-a diverse group of novel and important plant parasites. Rootknot Nematodes 1:483

Molinari S, Fanelli E, Leonetti P (2014) Expression of tomato salicylic acid (SA)-responsive pathogenesis-related genes in Mi-1-mediated and SA-induced resistance to root-knot nematodes. Molecular Plant Pathology 15:255-264

Mutar SS, Fattah FA (2013) Induced systemic resistance in tomato plants against Meloidogyne spp by seed treatment with $\beta$, amino butyric acid and benzothiadiazol., Journal of Biology Agriculture and Healthcare 3:49-55

Naalden D, Haegeman A, de Almeida-Engler J, Birhane Eshetu F, Bauters L, Gheysen G (2018) The Meloidogyne graminicola effector Mg16820 is secreted in the apoplast and cytoplasm to suppress plant host defense responses. Mol Plant Pathol 19:2416-2430

Nahar K, Kyndt T, De Vleesschauwer D, Höfte M, Gheysen G (2011) The jasmonate pathway is a key player in systemically induced defense against root knot nematodes in rice. Plant physiology 157:305-316

Nguyễn PV et al. (2014) Meloidogyne incognita-rice (Oryza sativa) interaction: a new model system to study plant-rootknot nematode interactions in monocotyledons. Rice 7:23 
Nguyen C-N et al. (2018) A root-knot nematode small glycine and cysteine-rich secreted effector, MiSGCR1, is involved in plant parasitism. New Phytol 217:687-699

Niu J et al. (2016) Msp40 effector of root-knot nematode manipulates plant immunity to facilitate parasitism. Sci Rep 6: 19443

Noir S, Anthony F, Bertrand B, Combes MC, Lashermes P (2003) Identification of a major gene (Mex-1) from Coffea canephora conferring resistance to Meloidogyne exigua in Coffea arabica. Plant Pathol 52:97-103

Palomares-Rius JE, Castillo P, Rapoport H, Archidona-Yuste A, Tzortzakakis EA (2015) Host reaction of Aloe vera infected by Meloidogyne incognita and M. javanica in Crete Island (Greece). European Journal of Plant Pathology 142:887-892

Postnikova OA, Hult M, Shao J, Skantar A, Nemchinov LG (2015) Transcriptome analysis of resistant and susceptible alfalfa cultivars infected with root-knot nematode Meloidogyne incognita. PLoS One 10:e0118269

Przybylska A, Kornobis F, Obrępalska-Stęplowska A (2018) Analysis of defense gene expression changes in susceptible and tolerant cultivars of maize (Zea mays) upon Meloidogyne arenaria infection. Physiol Mol Plant Pathol

Qtu J, Hallmann J, Kokalis-Burelle N, Weaver D, RodríguezKábana R, Tuzun S (1997) Activity and differential induction of chitinase isozymes in soybean cultivars resistant or susceptible to root-knot nematodes. J Nematol 29:523

Rashid MH, Al-Mamun M, Uddin MN (2017) How durable is root knot nematode resistance in tomato? Plant Breeding and Biotechnology 5:143-162

Reymond P, Farmer EE (1998) Jasmonate and salicylate as global signals for defense gene expression. Current opinion in plant biology 1:404-411

Roberts PA (1992) Current status of the availability, development, and use of host plant resistance to nematodes. J Nematol 24: 213

Rodiuc N, Vieira P, Banora MY, de Almeida Engler J (2014) On the track of transfer cell formation by specialized plantparasitic nematodes. Front Plant Sci 5

Rosso M-N, Favery B, Piotte C, Arthaud L, de Boer JM, Hussey RS, Bakker J, Baum TJ, Abad P (1999) Isolation of a cDNA encoding a $\beta-1,4$-endoglucanase in the root-knot nematode Meloidogyne incognita and expression analysis during plant parasitism. Mol Plant-Microbe Interact 12:585-591

Rosso M-N, Hussey RS, Davis EL, Smant G, Baum TJ, Abad P, Mitchum MG (2012) 13 nematode effector proteins: targets and functions in plant parasitism effectors in plant-microbe interactions

Sato K, Kadota Y, Shirasu K (2019) Plant immune responses to plant parasitic nematodes Frontiers in Plant Science 10:1165

Seid A, Fininsa C, Mekete T, Decraemer W, Wesemael WM (2015) Tomato (Solanum lycopersicum) and root-knot nematodes (Meloidogyne spp.)-a century-old battle. Nematology 17:995-1009

Shah SJ et al. (2017) Damage-associated responses of the host contribute to defence against cyst nematodes but not rootknot nematodes. Journal of experimental botany 68:59495960.

Shi Q et al. (2018a) The novel secreted Meloidogyne incognita effector MiISE6 targets the host nucleus and facilitates parasitism in Arabidopsis Frontiers in plant science 9. https://doi. org/10.3389/fpls.2018.00252
Shi Q et al. (2018b) A Meloidogyne incognita effector MiISE5 suppresses programmed cell death to promote parasitism in host plant. Sci Rep 8:7256

Shukla N et al. (2018) Transcriptome analysis of root-knot nematode (Meloidogyne incognita)-infected tomato (Solanum lycopersicum) roots reveals complex gene expression profiles and metabolic networks of both host and nematode during susceptible and resistance responses. Mol Plant Pathol 19:615-633

Siddique S, Grundler FM (2018) Parasitic nematodes manipulate plant development to establish feeding sites. Current opinion in microbiology 46:102-108

Siddiqui I, Shaukat S (2004) Systemic resistance in tomato induced by biocontrol bacteria against the root-knot nematode, Meloidogyne javanica is independent of salicylic acid production. J Phytopathol 152:48-54

Silva RV, Oliveira RD, Ferreira PS, Ferreira AO, Rodrigues FA (2013) Defense responses to Meloidogyne exigua in resistant coffee cultivar and non-host plant. Tropical Plant Pathology 38:114-121

Smant G et al. (1998) Endogenous cellulases in animals: isolation of $\beta$-1, 4-endoglucanase genes from two species of plantparasitic cyst nematodes. Proc Natl Acad Sci 95:4906-4911

Sobczak M, Fudali S, Wieczorek K (2011) Cell wall modifications induced by nematodes. Genomics and molecular genetics of plant-nematode interactions. Springer, In, pp 395-422

Spoel SH, Johnson JS, Dong X (2007) Regulation of tradeoffs between plant defenses against pathogens with different lifestyles. Proceedings of the National Academy of Sciences 104:18842-18847

Starr J, Yang W, Yan Y, Crutcher F, Kolomiets M (2014) Expression of phenylalanine ammonia lyase genes in maize lines differing in susceptibility to meloidogyne incognita. Journal of nematology 46:360

Teixeira MA, Wei L, Kaloshian I (2016) Root-knot nematodes induce pattern-triggered immunity in Arabidopsis thaliana roots. New Phytologist 211:276-287

Tirumalaraju SV, Jain M, Gallo M (2011) Differential gene expression in roots of nematode-resistant and-susceptible peanut (Arachis hypogaea) cultivars in response to early stages of peanut root-knot nematode (Meloidogyne arenaria) parasitization. J Plant Physiol 168:481-492

Veronico P, Paciolla C, Pomar F, De Leonardis S, García-Ulloa A, Melillo MT (2018) Changes in lignin biosynthesis and monomer composition in response to benzothiadiazole and rootknot nematode Meloidogyne incognita infection in tomato. Journal of plant physiology 230:40-50

Vieira P, Gleason C (2019) Plant-parasitic nematode effectorsinsights into their diversity and new tools for their identification. Curr Opin Plant Biol 50:37-43

Villeth GRC, Carmo LST, Silva LP, Fontes W, Grynberg P, Saraiva M, Brasileiro ACM, Carneiro RMD, Oliveira JTA, Grossi-de-Sá MF, Mehta A (2015) Cowpea-interaction: Root proteomic analysis during early stages of nematode infection. Proteomics 15(10):1746-1759

Vos C et al. (2013) Mycorrhiza-induced resistance against the root-knot nematode Meloidogyne incognita involves priming of defense gene responses in tomato. Soil Biology and Biochemistry 60:45-54

Wang X et al. (2018) A novel Meloidogyne incognita chorismate mutase effector suppresses plant immunity by manipulating 
the salicylic acid pathway and functions mainly during the early stages of nematode parasitism. Plant Pathology

Wesemael WM, Viaene N, Moens M (2011) Root-knot nematodes (Meloidogyne spp.) in Europe. Nematology 13:3-16

Wielkopolan B, Krawczyk K, Obrępalska-Stęplowska A (2018) Gene expression of serine and cysteine proteinase inhibitors during cereal leaf beetle larvae feeding on wheat: the role of insect-associated microorganisms. Arthropod Plant Interact 12:601-612

Wu W-W, Shen H-L, Yang W-C (2009) Sources for heat-stable resistance to southern root-knot nematode (Meloidogyne incognita) in Solanum lycopersicum. Agric Sci China 8:697702

Xie J, Li S, Mo C, Wang G, Xiao X, Xiao Y (2016) A novel Meloidogyne incognita effector Misp12 suppresses plant defense response at latter stages of nematode parasitism. Front Plant Sci 7:964

Xing X, Li X, Zhang M, Wang Y, Liu B, Xi Q, Zhao K, Wu Y, Yang T (2017) Transcriptome analysis of resistant and susceptible tobacco (Nicotiana tabacum) in response to rootknot nematode Meloidogyne incognita infection. Biochem Biophys Res Commun 482:1114-1121
Yan Y et al. (1998) Genomic organization of four $\beta-1,4-$ endoglucanase genes in plant-parasitic cyst nematodes and its evolutionary implications. Gene 220:61-70

Zhou J et al. (2015) Involvement of nitric oxide in the jasmonatedependent basal defense against root-knot nematode in tomato plants. Front Plant Sci 6:193

Zhuo K, Chen J, Lin B, Wang J, Sun F, Hu L, Liao J (2017) A novel Meloidogyne enterolobii effector MeTCTP promotes parasitism by suppressing programmed cell death in host plants. Molecular plant pathology 18:45-54

Zhuo K, Naalden D, Nowak S, Xuan Huy N, Bauters L, Gheysen G (2019) A Meloidogyne graminicola C-type lectin, $\mathrm{Mg} 01965$, is secreted into the host apoplast to suppress plant defence and promote parasitism. Mol Plant Pathol 20:346355

Publisher's note Springer Nature remains neutral with regard to jurisdictional claims in published maps and institutional affiliations. 